\title{
An Investigation of Strength Properties of Concrete Core Samples Obtained in Different Heights and Lines
}

\author{
Kadir Güçlüer*, Osman Günaydın ** \\ *(Department of Construction, Adlyaman University, Adlyaman/Turkey \\ ** (Department of Civil Engineering , Adlyaman University, Adlyaman/Turkey
}

\begin{abstract}
Concrete is a composite building material wich has a high usage area. The quality and properties of the concrete material produced may vary according to the type of application and the application area. Especially it is important to examine these changes of the concrete used in the bearing elements. For this purpose, in this study, concrete core specimens were taken in vertical and horizontal directions from different height points of the concrete columns produced in 40x40×250 cm dimensions. Ultrasonic pulse velocity and compressive strength measurements were performed on cored specimens. The obtained data are compared with each other and the regions with the highest and lowest values of strength are determined and the strength loss is expressed as a percentage. The highest strength values were observed in the samples taken in the lower region and in the vertical direction.
\end{abstract}

Keywords - Concrete core, column, compressive strength.

\section{INTRODUCTION}

Concrete is an artificial building material obtained by mixing together, aggregate, cement, water and some minerals and chemical additives when necessary, initially obtaining the desired mold shape since it is fluid at the beginning, and after hardening it can provide the necessary strength for a certain carrying force with high durability [1].

The compressive strength of concrete is taken into account when the constructions are designed. Knowing the compressive strength of concrete also provides information another properties such as shear strength, tensile strength, abrasion resistance and permeability [2].

Different methods are used to determine the compressive strength of concrete. Standard cubic or cylindrical test samples are taken during the pouring of the concrete instead for similar tests for determining the quality of concrete. The strength values of these samples are determined according to the 28 day compressive strength [3].

The most important property expected from the concrete is that the compressive strength is high. High-strength concrete generally has low void ratio, low water permeability, resistance to abrasion and resistance to external influences [4].

The compressive strength of concrete is vital to the structural integrity of the reinforced concrete system. Therefore it is very important to know the compressive strengths of different building elements after the completion of construction, both in construction phase and in control and evaluation [5].

Concrete compressive strength is one of the important parameters affecting the seismic performance of construction. For this reason, it is very important to determine the concrete strength of the reinforced concrete structures as close as possible to the seismic performance [6].

Determination of the concrete compressive strength includes damaged methods such as the core method in which a section cut through hardened concrete is tested and undamaged methods in which the surface hardness or the speed of ultrasonic waves is measured [7].

The only purpose of taking the core from the concrete is not to obtain data for evaluation of structural adequacy against earthquake. In the case of surface abnormalities, in determining the depth of cracks, in various situations, can be taken to get the core in concrete [8].

\section{MATERIALS AND METHODS}

In this study, ready mixed concrete was used which produced in the concrete plant. As binder material CEM I $42.5 \mathrm{R}$ type cement according to TS EN 197-1 [9] was used. Natural aggregate material was selected as coarse aggregate. The mixing ratios of the materials entering the $1 \mathrm{~m}^{3}$ concrete composition are given in Table 1.

In this study, 40x40x250 cm columns were produced and ready-mixed concrete was placed in one operation without vibrator application. After storage for 5 months outdoor conditions throughout the column was transferred to a special facility, to be broken and exploded wherein the lower-middleupper region of $40 \times 40 \times 25 \mathrm{~cm}$ in size (Figure 1). 4 pieces of $10 \times 20 \mathrm{~cm}$ cylindrical core samples were taken out from the separated parts in horizontal and vertical directions according to the concrete casting 
direction and then dimensioned to be slenderness ratio 1 .

Table 1. Amount of materials entering $1 \mathrm{~m}^{3}$ concrete composition $(\mathrm{kg})$

\begin{tabular}{|l|l|l|l|l|}
\hline Materials & Cement & Water & Fine aggregate & Coarse Aggregate \\
\hline Amount & 320 & 160 & 850 & 1150 \\
\hline
\end{tabular}
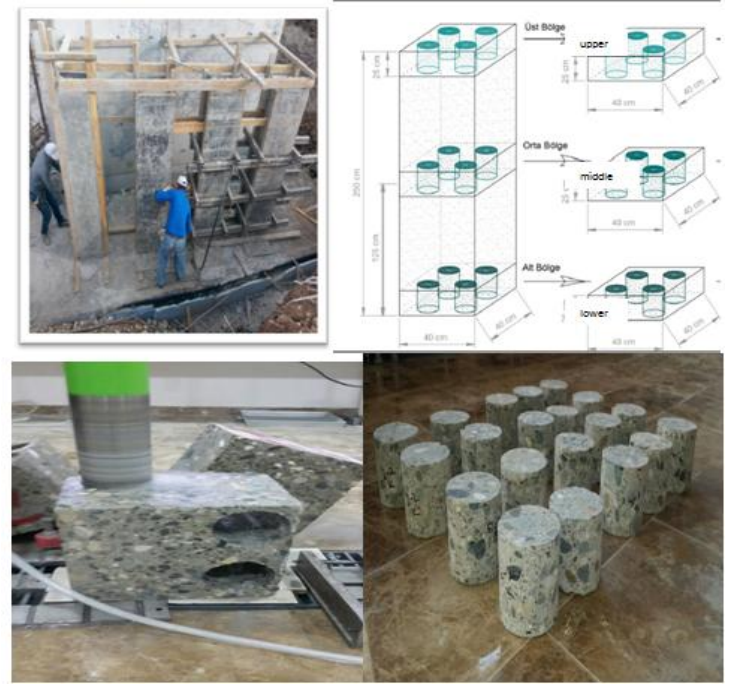

Figure 1. Column application and removal of core samples

\subsection{Ultrasonic Pulse Velocity Methods}

Ultrasonic pulse velocity measurements were made according to ASTM C 597 [10]. Readings were performed with each sample surface saturated with dry water.

\subsection{Compressive Strength Methods}

Concrete core samples are broken in accordance with TS EN 12390-3 [12] and TS EN 13791 [11] at a loading speed of $6 \mathrm{MPa} / \mathrm{sec}$ in a 200 ton pressure press in Adryaman University Civil Engineering Construction Materials Lab.

\section{FINDINGS}

\subsection{Ultrasonic Pulse Velocity Findings}

The ultrasonic pulse velocity data of the concrete core samples taken in horizontal and vertical directions with respect to the direction of concrete casting are given in Table 2 . When the data were examined, it was observed that the highest pass-through values were read from the samples taken in the horizontal direction from the middle region. When the samples in all the regions are examined, higher results are obtained in the concrete cores taken in the horizontal direction than in the samples taken in the vertical direction.
Table 2. Ultrasonic pulse velocity data for concrete core samples

\begin{tabular}{|c|c|c|c|}
\hline \multicolumn{2}{|c|}{ Series Name } & $\begin{array}{l}\text { Ultrasonic Pulse } \\
\text { Velocity }(\mathbf{k m} / \mathbf{s n})\end{array}$ & $\begin{array}{l}\text { Average } \\
(\mathrm{km} / \mathbf{s n})\end{array}$ \\
\hline \multirow{3}{*}{$\begin{array}{l}\text { Lower } \\
\text { Horizontal }\end{array}$} & 1 & 4,54 & \multirow{3}{*}{4,52} \\
\hline & 2 & 4,56 & \\
\hline & 3 & 4,47 & \\
\hline \multirow{3}{*}{$\begin{array}{l}\text { Lower } \\
\text { Vertical }\end{array}$} & 1 & 4,33 & \multirow[t]{3}{*}{4,50} \\
\hline & 2 & 4,57 & \\
\hline & 3 & 4,37 & \\
\hline \multirow{3}{*}{$\begin{array}{l}\text { Middle } \\
\text { Horizontal }\end{array}$} & 1 & 4,62 & \multirow[t]{3}{*}{4,75} \\
\hline & 2 & 4,91 & \\
\hline & 3 & 4,66 & \\
\hline \multirow{3}{*}{$\begin{array}{l}\text { Middle } \\
\text { Vertical }\end{array}$} & 1 & 4,72 & \multirow[t]{3}{*}{4,64} \\
\hline & 2 & 4,56 & \\
\hline & 3 & 4,65 & \\
\hline \multirow{3}{*}{$\begin{array}{l}\text { Upper } \\
\text { Horizontal }\end{array}$} & 1 & 4,58 & \multirow[t]{3}{*}{4,61} \\
\hline & 2 & 4,75 & \\
\hline & 3 & 4,52 & \\
\hline \multirow{3}{*}{$\begin{array}{l}\text { Upper } \\
\text { Vertical }\end{array}$} & 1 & 4,76 & \multirow[t]{3}{*}{4,58} \\
\hline & 2 & 4,45 & \\
\hline & 3 & 4,54 & \\
\hline
\end{tabular}

\subsection{Compressive Strength Findings}

The compressive strength data of the concrete core samples taken in the horizontal and vertical directions with according to the concrete casting direction are given in Table 3 . When the strength values of the specimens are examined, it is observed that the strength values of the samples from the lower region to the upper region of the column are decreased. It is also seen that the strength values of samples taken in the vertical direction in the concrete core samples in the Lower-MiddleUpper regions are higher.

Table 3. Strength values of concrete core samples taken in horizontal and vertical direction

\begin{tabular}{|c|c|c|c|}
\hline \multicolumn{2}{|c|}{ Series Name } & \multirow{2}{*}{$\begin{array}{l}\text { Compressive } \\
\text { Strength (MPa) } \\
22,99\end{array}$} & \multirow{2}{*}{$\begin{array}{l}\begin{array}{l}\text { Average } \\
\text { (MPa) }\end{array} \\
25,62\end{array}$} \\
\hline \multirow{3}{*}{$\begin{array}{l}\text { Lower } \\
\text { Horizontal }\end{array}$} & 1 & & \\
\hline & 2 & 24,23 & \\
\hline & 3 & 29,65 & \\
\hline \multirow{3}{*}{$\begin{array}{l}\text { Lower } \\
\text { Vertical }\end{array}$} & 1 & 29,64 & \multirow[t]{3}{*}{26,74} \\
\hline & 2 & 26,61 & \\
\hline & 3 & 23,98 & \\
\hline \multirow{3}{*}{$\begin{array}{l}\text { Middle } \\
\text { Horizontal }\end{array}$} & 1 & 23,86 & \multirow[t]{3}{*}{25,05} \\
\hline & 2 & 26,70 & \\
\hline & 3 & 24,59 & \\
\hline \multirow{3}{*}{$\begin{array}{l}\text { Middle } \\
\text { Vertical }\end{array}$} & 1 & 24,23 & \multirow[t]{3}{*}{25,57} \\
\hline & 2 & 27,40 & \\
\hline & 3 & 25,08 & \\
\hline \multirow{3}{*}{$\begin{array}{l}\text { Upper } \\
\text { Horizontal }\end{array}$} & 1 & 21,29 & \multirow[t]{3}{*}{20,91} \\
\hline & 2 & 21,14 & \\
\hline & 3 & 20,31 & \\
\hline \multirow{3}{*}{$\begin{array}{l}\text { Upper } \\
\text { Vertical }\end{array}$} & 1 & 23,14 & \multirow[t]{3}{*}{22,27} \\
\hline & 2 & 22,15 & \\
\hline & 3 & 21,53 & \\
\hline
\end{tabular}


The average value of the compressive strength values of the concrete core samples taken in the horizontal (red line in Fig.) direction was determined as 25.62 $\mathrm{MPa}$ in the lower zone, 25.05 $\mathrm{MPa}$ in the middle zone and 20.91 MPa in the upper zone. The average values of the compressive strength values of the concrete core specimens taken in the vertical (blue line Fig.) direction were determined as $26.74 \mathrm{MPa}$ in the lower region, 25.57 $\mathrm{MPa}$ in the middle region and $22.27 \mathrm{MPa}$ in the upper region (Figure 2).

In the spilled column concrete, the strength values in the lower region are assumed to be $100 \%$, and accordingly the change in strength with respect to the core samples taken in the horizontal and vertical directions together with the middle and upper regions is shown in Fig. 3.

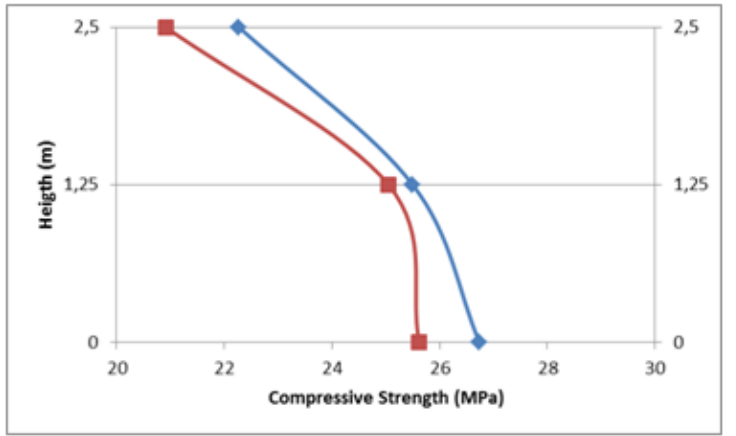

Figure 2. Change of compressive strength of core specimens taken in horizontal and vertical direction

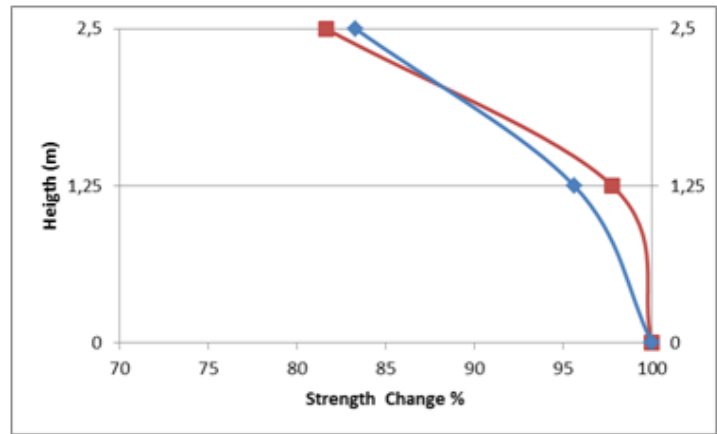

Figure 3. The percentage change in compressive strength of concrete core specimens by area

When the changes of the concrete core samples taken in the horizontal direction according to the direction of concrete casting were examined, the percentage value in the middle region was determined as \%97.77 and in the upper region $\% 81.61$. When it goes up from the lower region, there is a loss of compressive strength ratio \% 2.23 , this value $\% 18.39$ in the upper region. When the changes of the concrete core samples taken in the vertical direction with respect to the concrete casting direction were examined, the strength value in the middle region was determined as \%95.62 and in the upper region \%83.28. In the cored specimens taken in the vertical direction, \%4,38 strength loss was observed in the middle region and \%16,72 strength loss was observed in the upper region.

\section{CONCLUSION}

This study investigated that the effect of concrete core specimens taken from different parts of the column in different directions and on the compressive strength, it was concluded that:

$>$ When the compressive strengths of the core elements taken in different directions in the column were evaluated, it was determined that the strength values of the concrete cores taken in the vertical direction with respect to the concrete casting direction were higher than the concrete cores taken in the horizontal direction.

$>$ The compressive strengths of the concrete core samples taken in the horizontal direction with respect to the concrete casting direction were determined as $25.62 \mathrm{MPa}$ in the lower zone, 25.05 MPa in the middle zone and 20.91 MPa in the upper zone.

$>$ The compressive strengths of concrete core specimens taken in vertical direction with respect to the direction of concrete casting were determined as $26.74 \mathrm{MPa}$ in the lower region, 25.57 $\mathrm{MPa}$ in the middle region and 22.27 $\mathrm{MPa}$ in the upper region.

$>$ When the compressive strength values in the regional case are examined, it is observed that the highest strength values are in the lower region of the concrete core samples taken in the horizontal and vertical direction, and the lowest strength values are in the upper region of the column element.

$>$ When the strength loss in the concrete cores in the horizontal direction was investigated locally, it was determined that the strength loss was $\% 2.23$ in the middle region and \%18.39 in the upper region.

$>$ When the strength loss in the concrete cores in the vertical direction was investigated locally, it was determined that the strength loss was $\% 4.38$ in the middle region and \%16.72 in the upper region.

\section{REFERENCES}

[1] Topçu, İ.B. Beton Teknolojisi. Uğur Ofset A.Ş., Eskişehir, Türkiye, 2006.

[2] Erdoğan, T.Y. Beton. METU Press, Ankara, Türkiye, 2007.

[3] Uzunoğlu, M., Beycioğlu, A., Serin, S., Güner, S., M., Farklı Yönlerden Alınan Beton Karot Numunelerin Basınç Dayanımlarının Alternatif Bir Yöntemle Tahmini. 5. Uluslararası Ileri Teknolojiler 
Sempozyumu (IATS'09), 13-15 May1s 2009, Karabük, Türkiye.

[4] Baradan, B., Yazıc1, H., Ün, H., Betonarme Yapılarda Kalıcılık - Durabilite. Dokuz Eylül Üniversitesi Mühendislik Fakültesi Yayınları, İzmir, Türkiye, 2002.

[5] Yazıc1, Ş., Göktepe, B., A, Altun, S., Karaman, V., Sertleşmiş beton basınç dayanımının belirlenmesinde kullanılan ts10465 ve ts en 12504-1 üzerine bir değerlendirme., $\quad D E \ddot{U} \quad$ Mühendislik Fakültesi Fen Ve Mühendislik Dergisi Cilt: 8 Sayı: 1 s. 119-128 Ocak 2006.

[6] İnel, M., Özmen, H.B., Çaycı, B.T., Ün, H., Mevcut Betonarme Yapılarda Karot Numune Sayısı İle Beton Basınç Dayanımı İlişkisinin Değerlendirilmesi. 2. Türkiye Deprem Mühendisliği ve Sismoloji Konferansl, 25-27 Eylül 2013, Hatay.

[7] Uysal, M., Yılmaz, K., Ulugol, H., Betonarme eleman tipinin sertleşmiş betonun dayanım özelliklerine etkisi. ISITES 2014 ,Karabük, Türkiye.

[8] Yaman, Ö., Şengül, Ö., Selçuk, H., Çalıkuş, O., Kara, İ., Erdem, Ş., Özgür, D., Mevcut yapılardaki beton basınç dayanımlarının karotlarla belirlenmesi. TMH - $487-s: 40$ 43.2015/4

[9] TS EN 197-1, Çimento- Bölüm 1: Genel Çimentolar- Bileşim, Özellikler ve Uygunluk Kriterleri, Türk Standartları Enstitüsü, Ankara, Türkiye, 2002.

[10] ASTM C597-09, Standard Test Method for Pulse Velocity Through Concrete, American Concrete Institute, 2009.

[11] TS EN 13791, Basınç Dayanımının Yapılar ve Öndökümlü Beton Bileşenlerde Yerinde Tayini, Türk Standartları Enstitüsü, 2007.

[12] TS EN 12390-3, Beton-Sertleşmiş Beton Deneyleri-Bölüm 3: Deney Numunelerinde Basınç Dayanımının Tayini, Türk Standartları Enstitüsü, Ankara, 2003. 